\title{
Fungi Tanah Perkebunan Kopi dan Potensinya sebagai Agen Antagonis (The Soil Fungi of The Coffee Plantation And Its Potential as Antagonistic Agent)
}

\author{
Samingan ${ }^{* *}$ \\ 1) Program Studi Pendidikan Biologi FKIP Unsyiah Banda Aceh 23111 \\ *Email: samingan@fkip.unsyiah.ac.id
}

Diterima 9 Februari 2015, diterima untuk dipublikasikan 25 Februari 2015

\begin{abstract}
Abstrak
Fungi tanah dari perkebunan kopi telah diisolasi untuk mendapatkan fungi antagonistik sebagai pengendali hayati untuk patogen busuk akar kopi. Sampel diambil dari 3 kecamatan di Kabupaten Bener Meriah Provinsi Aceh. Isolasi fungi dilakukan dengan metode pengenceran. Hasil penelitian menunjukkan bahwa fungi yang diisolasi dari perkebunan kopi Kabupaten Bener Meriah tidak menunjukkan adanya perbedaan indeks keragaman dan kemerataan. Ditemukan tiga kelompok fungi yang dominan ditemukan di 3 lokasi pengambilan sampel, yaitu Aspergillus, Penicillium dan Trichoderma. Hasil uji antagonistik menunjukkan bahwa Trichoderma sp2 memiliki kemampuan antagonistik yang lebih tinggi terhadap fungi patogen busuk akar kopi.

Kata-kata kunci: fungi antagonis, fungi patogen, fungi tanah, busuk akar kopi
\end{abstract}

\section{Abstract}

Soil fungi of the coffee plantation was isolated to find the antagonistic fungi as biocontrol agent for pathogenic fungi of coffee root rot. Samples were obtained from three subdistrict of Bener Meriah Regency in Aceh Province. Fungi isolates were obtained by the dilution method. The results showed that the fungi isolates from coffee plantation in Bener Meriah Regency were not different in diversity and evenness indices. There were three groups of dominant fungi in these 3 sampling locations, i.e. Aspergillus, Penicillium and Trichoderma. Based on antagonistic test, Trichoderma sp2 was able to inhibit the pathogenic fungi of coffee root rot.

Key words: antagonistic fungi, pathogenic fungi, soil fungi, coffee root rot

\section{PENDAHULUAN}

Keberadaan fungi pada tanah berperan sangat penting sebagai dekomposer dan pengendali keseimbangan populasi. Sebagai dekomposer fungi mampu menguraikan senyawa organik komplek menjadi senyawa sederhana. Beberapa fungi dilaporkan mempunyai kemampuan sebagai dekomposer pada lantai hutan Acacia mangium diantaranya Trichoderma sp., Curvularia sp., Alternaria sp., Fusarium dan Pythium (Samingan et al. 1999, Samingan et al.
2008). Selanjutnya dilaporkan juga bahwa pada tanah sering sekali diperoleh fungi Aspetrgillus, Fusarium, Penicillium dan Trichoderma (Gams 2007). Sebagai pengendali populasi, fungi mempunyai kemampuan untuk melakukan interaksi antagonis dengan fungi lain. Interaksi antagonis fungi, secara tradisional diklasifikasikan sebagai antibiosis, mikoparasitisme dan kompetisi (Widyastuti 2006). Antibiosis terjadi ketika antagonisme antara dua fungi dimana fungi yang satu menguasi yang lainnya. 
Mikoparasitisme yaitu parasitisme satu fungi dengan fungi lainnya dan kompetisi terjadi ketika dua atau lebih mikroorganisme membutuhkan lebih banyak sumberdaya dari pada yang tersedia. Interaksi antagonis antibiosis maupun mikoparasitisme hampir selalu melibatkan kompetisi dalam hal nutrisi (Ghisalberti dan Sivasithamparan 1991). Interaksi antagonis fungi tanah ini dapat diaplikasikan dalam pengendali hayati untuk mengendalikan fungi patogen.

Pengendalian hayati pada prinsipnya memanfaatkan agen hayati untuk menekan pertumbuhan organisme lain yang bersifat patogen terhadap tanaman budi daya. Banyak fungi yang mempunyai kemampuan menekan aktivitas patogen yang dapat disolasi dari tanah, diantaranya Trichoderma dan Gliocladium. Trichoderma dan Gliocladium merupakan agen pengendali hayati bersifat mikoparasit yang banyak digunakan untuk menangani penyakit busuk akar pada cocoa, kopi dan jambu mente, namun penerapannya harus pada mikroklimat yang sesuai agar aktivitas antagonisnya dapat bekerja optimum (Adejumo 2005). Kemampuan antagonistik Trichoderma telah diujikan terhadap beberapa patogen tanaman seperti Ganoderma spp., Rigidoporus microporus, Rhizoctonia spp., Fusarium sp. dan Sclerotium rolfsii. Hasilnya menunjukkan bahwa Trichoderma dapat secara efektif menekan pertumbuhan fungi patogen secara in vitro dan di rumah kaca (Widyastuti 2006)

Keberadaan fungi pada tanah
sudah banyak informasi yang
dilaporkan, namun keberadaan fungi
tanah pada perkebunan kopi rakyat
terutama di Kabupaten Bener Meriah
Aceh masih belum diperoleh banyak
informasi. Banyaknya jenis fungi yang
sering ditemukan di dalam tanah

sangat menarik untuk diteliti terutama pada perkebunan kopi karena keberadaan fungi tersebut dapat berasosiasi dengan tanaman terutama tanaman kopi. Asosiasi tersebut jika dilihat dari perspektif kepentingan manusia ada yang menguntungkan dan ada juga yang merugikan. Hasil penelitian ini diharapkan dapat memberikan informasi keberadaan jenis fungi yang tumbuh di tanah perkebunan kopi dan potensinya sebagai pengendali hayati yang dapat dimanfaatkan sebagai agen pengendali hayati terhadap fungi patogen. Dengan demikian dapat dijadikan sebagai salah satu pemecahan masalah untuk menangani fungi pathogen pada akar kopi di Kabupaten Bener Meriah.

\section{METODE}

a. Pengambilan sampel di lapangan

Pengambilan sampel fungi tanah masing-masing sebanyak 10 titik dilakukan di tiga kecamatan Kabupaten Bener Meriah, yaitu Kecamatan Pintu Rime Gayo, Kecamatan Timang Gajah dan Kecamatan Bukit. Sampel diambil dengan cara menggali tanah dengan cangkul sedalam $20-30 \mathrm{~cm}$ pada areal seluas $50 \times 50 \mathrm{~cm}$ di sekitar tanaman kopi yang sehat. Tanah yang telah digali, diaduk sampai homogen lalu diambil sebanyak \pm 300 gram dan dimasukkan ke dalam kantong plastik steril, diberi label dan disimpan untuk dibawa ke laboratorium.

\section{b. Isolasi dan identifikasi fungi tanah}

Sampel tanah dari lapangan masing-masing diambil sebanyak $10 \mathrm{~g}$ dan dimasukkan ke dalam beaker glass berisi $90 \mathrm{ml}$ akuades steril. Kemudian digoyang dengan vortex selama \pm 3 menit untuk melepaskan spora dan miselium fungi dari tanah. Pengenceran suspensi di dalam laminar air flow dilakukan sampai 1000 kali. Hasil pengenceran 100 sampai 1000 kali, masing-masing diambil $1 \mathrm{ml}$ dengan 
pipet lalu dimasukkan dalam cawan Petri steril. Media potato dextrose agar (PDA) yang telah ditambah klorampenikol ( $250 \mathrm{mg} / \mathrm{L})$ dan suhunya sekitar $40^{\circ} \mathrm{C}$, dituangkan ke dalam cawan yang telah diberi suspensi. Campuran media dan suspensi di dalam cawan kemudian digoyanggoyang agar tersebar merata. Masingmasing pengenceran diulang sebanyak dua kali. Setelah dingin setiap cawan disegel dengan selotip plastik agar tidak terkontaminasi lalu diinkubasikan dalam susu kamar.

Setelah 24 jam inkubasi dilakukan penghitungan jumlah koloni dari setiap jenis fungi yang tumbuh. Kemudian dilakukan isolasi untuk mendapatkan biakan murni terhadap jenis fungi yang tumbuh dengan cara memindahkan masing-masing isolat ke dalam media PDA. Setelah diperoleh biakan murni isolat-isolat tersebut dipindahkan dalam tabung reaksi besisi media PDA miring untuk disimpan sebagai spesimen.

Isolat yang diperoleh
diidentifikasi berdasarkan pada penampakan morfologi koloni, morflogi hifa dan struktur penghasil spora aseksualnya (melalui pengamatan di bawah mikroskop cahaya). Ciri-ciri dan struktur yang diamati dicocokkan dengan buku acuan yang digunakan untuk identifikasi. Buku-buku acuan yang digunakan untuk identifikasi adalah Breitenbach dan Kranzlin (1986), Mollach (1997), Pitt dan Hocking (1997), Kubicek dan Harman (1998), Fisher dan Cook (1998), Ganjar et al. (1999), Watanabe (2002) dan buku-buku lain yang mendukung.

c. Pengujian aktivitas antagonisme

Fungi hasil isolasi dari tanah perakaran kopi diuji kemampuan antagonistiknya secara individual terhadap Ganoderma sp. Masingmasing isolat diuji aktivitas antagonismenya dengan metode dual test pada media PDA. Pengujian dilakukan dengan menumbuhkan isolat fungi yang berpotensi sebagai pengendali hayati pada sisi kanan dan fungi patogen busuk akar pada sisi kiri media PDA padat dengan jarak dari sisi cawan masing-masing $\pm 3 \mathrm{~cm}$. Diameter koloni awal dibuat $0,5 \mathrm{~cm}$ dengan menggunakan pelubang gabus. Untuk mengetahui kemampuan aktivitas antagonisme masing-masing isolat dilakukan pengukuran persentase hambatan pada hari ke 3 setelah inokulasi. Pengukuran persentase hambatan dilakukan dengan mengukur radius koloni fungi patogen yang tidak berhadapan dengan antagonis dan radius koloni pathogen yang berhadapan dengan antagonis. Jarak antara koloni patogen dan koloni antagonis juga dicatat. Persentase hambatan dihitung dengan rumus:

$\mathrm{I}=\left(\mathrm{C}_{1}-\mathrm{C}_{2} / \mathrm{C}_{1} \times 100\right)$

(Khattabi et al. 2004)

Keterangan:

$\mathrm{I}=$ persentase hambatan,

$\mathrm{C}_{1}$ = radius koloni fungi patogen yang tidak berhadapan dengan antagonis, $\mathrm{C}_{2}$ = radius koloni fungi patogen yang berhadapan dengan antagonis.

d. Pengujian kemampuan tumbuh pengendali hayati terpilin pada media tumbuh kompos

Percobaan ini dilakukan untuk mengetahui pada media tumbuh yang mana pertumbuhan isolat fungi pengendali hayati terpilih dapat tumbuh dengan baik. Penumbuhan dilakukan pada media tumbuh dari kompos kulit buah kopi dan kulit biji kopi. Masingmasing media tumbuh dari kedua macam kompos diinkubasikan selama dua minggu. Kemudian masing-masing kompos tersebut diambil $\pm 25 \mathrm{~g}$ lalu dimasukkan ke dalam cawan petri. Selanjutnya media tersebut disterilkan 
dalam autoklaf selama 15 menit pada $121^{\circ} \mathrm{C}$ dan tekanan $1 \mathrm{~atm}$. Setelah dingin media tumbuh diinokulasikan dengan bibit pengendali hayati terpilih sebanyak $1 \mathrm{~g}$. Pengujian pada setiap media tumbuh diulang sebanyak tiga kali. Kemudian agen antagonis terpilih tersebut diinkubasikan pada suhu kamar selama satu minggu lalu dihitung jumlah populasinya. Media yang dapat menghasilkan jumlah populasi isolat fungi pengendali hayati yang tertinggi merupakan media yang akan digunakan untuk pengujian aplikasi pengendalian hayati terhadap patogen busuk akar kopi.

\section{HASIL DAN PEMBAHASAN}

Hasil isolasi fungi yang berasal dari tanah perkebunan kopi di Kabupaten Bener Meriah diperoleh 17 isolat fungi, dengan perincian 10 isolat diperoleh di Kecamatan Pintu Rime Gayo, 9 isolat di Kecamatan Timang Gajah dan 10 isolat di Kecamatan Bukit. Isolat fungi yang diperoleh di ketiga kecamatan tersebut disajikan pada Tabel 1.

Pada Tabel 1 terlihat bahwa fungi dari kelompok Aspergillus, Penicillium dan Trichoderma selalu didapatkan pada ketiga lokasi pengambilan sampel, sedangkan fungi yang lain tidak. Hal ini menunjukkan bahwa ketiga kelompok fungi tersebut merupakan fungi yang sering ditemukan di dalam tanah, sebagaimana dilaporkan oleh Gams (2007) bahwa pada tanah sering sekali diperoleh fungi Aspergillus, Fusarium, Penicillium dan Trichoderma. Fungi tersebut tergolong ke dalam subdivisi Deuteromycetes. Menurut Titus dan Pereira (2008) fungi dari kelompok Aspergillus, Trichoderma, Rhizoctonia, Penicillium, dan Gleosporium merupakan fungi yang umum ditemukan pada tanah perkebunan kopi.

Indeks keragaman dan indeks kemeratan fungi yang diperoleh dari tiga kecamatan lokasi pengambilan sampel ditunjukkan pada Gambar 1.

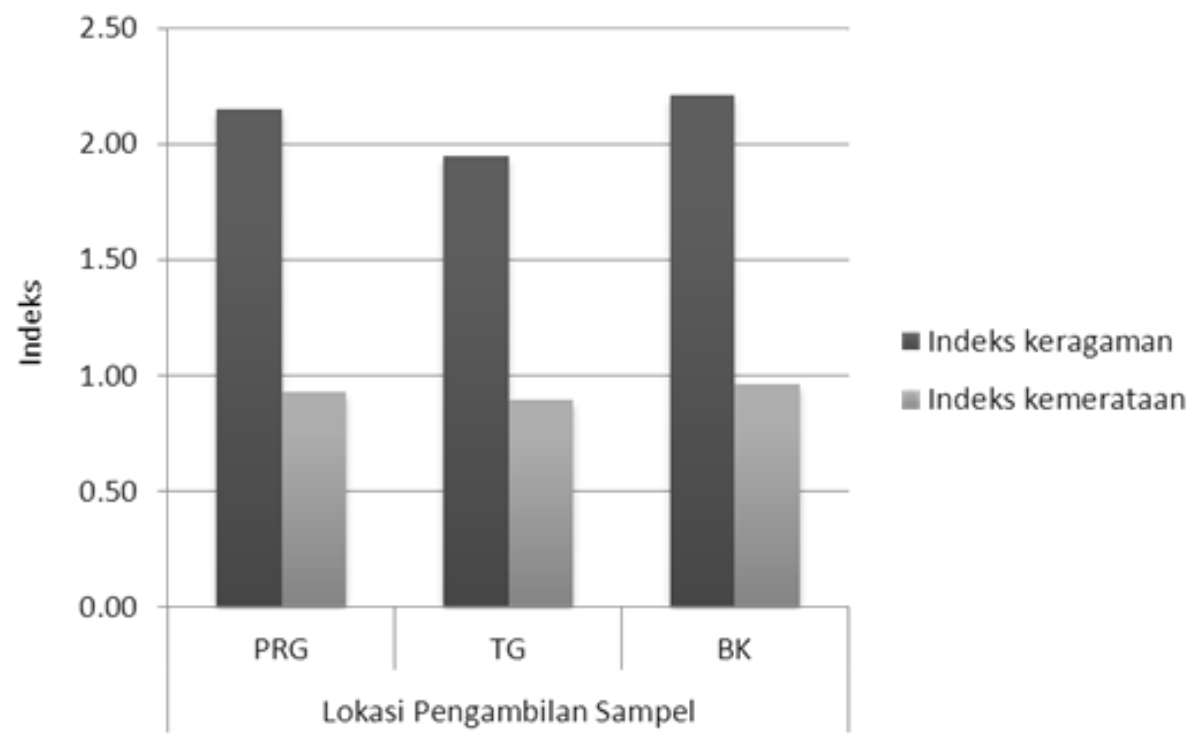

Gambar 1. Indeks keragaman dan indeks kemerataan fungi yang diisolasi dari tanah perkebunan kopi di Kabupaten Bener meriah. $P R G=$ Kecamatan Pintu Rime Gayo, TG = Kecamatan Timang Gajah, BK = Kecamatan Bukit 
Tabel 1. Isolat fungi yang diperoleh di Kabupaten Bener Meriah

\begin{tabular}{|c|c|c|c|c|}
\hline \multirow{2}{*}{ No } & \multirow{2}{*}{ Isolat fungi } & \multicolumn{3}{|c|}{ Lokasi pengambilan sampel } \\
\hline & & PRG & $\mathrm{TG}$ & $\mathrm{BK}$ \\
\hline 1 & Acremonium sp & $\sqrt{ }$ & & \\
\hline 2 & Aspergillus sp1 & $\sqrt{ }$ & $\sqrt{ }$ & $\sqrt{ }$ \\
\hline 3 & Aspergillus sp2 & $\sqrt{ }$ & & $\sqrt{ }$ \\
\hline 4 & Aspergillus sp3 & $\sqrt{ }$ & & \\
\hline 5 & Gliocladium sp & & $\sqrt{ }$ & $\sqrt{ }$ \\
\hline 6 & Humicola sp1 & $\sqrt{ }$ & & $\sqrt{ }$ \\
\hline 7 & Humicola sp2 & $\sqrt{ }$ & & $\sqrt{ }$ \\
\hline 8 & Paecilomyces sp & & $\sqrt{ }$ & \\
\hline 9 & Penicillium sp 1 & $\sqrt{ }$ & & $\sqrt{ }$ \\
\hline 10 & Penicillium sp 2 & & $\sqrt{ }$ & $\sqrt{ }$ \\
\hline 11 & Penicillium sp3 & & $\sqrt{ }$ & $\sqrt{ }$ \\
\hline 12 & Trichoderma sp1 & $\sqrt{ }$ & $\sqrt{ }$ & $\sqrt{ }$ \\
\hline 13 & Trichoderma sp2 & $\sqrt{ }$ & & \\
\hline 14 & Zopfiella latipes & & $\sqrt{ }$ & $\sqrt{ }$ \\
\hline 15 & Isolat Sp 1 & & $\sqrt{ }$ & \\
\hline 16 & Isolat Sp 2 & & $\sqrt{ }$ & \\
\hline 17 & Isolat Sp 3 & $\sqrt{ }$ & & \\
\hline & Jumlah & 10 & 9 & 10 \\
\hline
\end{tabular}

Keterangan: PRG = Kecamatan Pintu Rime Gayo, TG = Kecamatan Timang Gajah, $\mathrm{BK}=$ Kecamatan Bukit

Pada Gambar 1 terlihat bahwa indeks keragaman dari fungi yang ditemukan pada tiga lokasi pengambilan sampel antara 1,95 sampai 2,21. Demikian juga dengan indeks kemerataannya antara 0,89 sampai 0,96 . Hal ini disebabkan karena kondisi lingkungan tanah pada ketiga lokasi pengambilan sampel hampir sama, seperti suhu tanah antara 20 sampai $22^{\circ} \mathrm{C}, \mathrm{pH}$ tanah 5,4 sampai 6,4 dan kelembapan udara antara 80 sampai $85 \%$. Kondisi lingkungan yang hampir sama pada ketiga lokasi tersebut menyebabkan jenis fungi yang ditemukan dan keragamannya tidak berbeda.

Kehadiran Penicillium dan Aspergillus pada tanah perkebunan dapat memberikan dampak positif. Pada perkebunan kelapa sawit kehadiran fungi tersebut dapat mereduksi kejadian penyakit busuk pangkal batang antara $5 \%$ sampai $40 \%$ (Sariah dan Zakaria 2000). Demikian juga dengan kehadiran Trichoderma yang secara ekologis dapat memberikan dampak positif pada tanah perkebunan kopi karena mempunyai kemampuan antagonistik yang kuat terhadap Ganoderma.

Trichoderma merupakan salah satu fungi tanah yang dominan dan mempunyai variasi habitat yang luas. Sebagai organisme saprob yang memilki pertumbuhan cepat, Trichoderma dapat berkompetisi secara ekologis dalam waktu yang lama dan mampu mengkolonisasi berbagai substrat yang ada di lantai perkebunan. Interaksi antagonis antara Trichoderma dengan fungi lain, secara tradisional diklasifikasikan menjadi tiga, yaitu antibiosis, mikoparasitisme dan kompetisi, namun kemampuan antagonistik Trichoderma bersifat mikoparasit hiperparasit (Widyastuti 2006). Tiga spesies Trichoderma yang telah diuji efektivitasnya terhadap penekanan pertumbuhan Ganoderma pilippii yang diisolasi dari berbagai macam pohon. Hasilnya menunjukkan Trichoderma reesei paling efektif sebagai mikoparasit diikuti oleh $T$. koningii dan $T$. harzianum (Widyastuti 2006). 


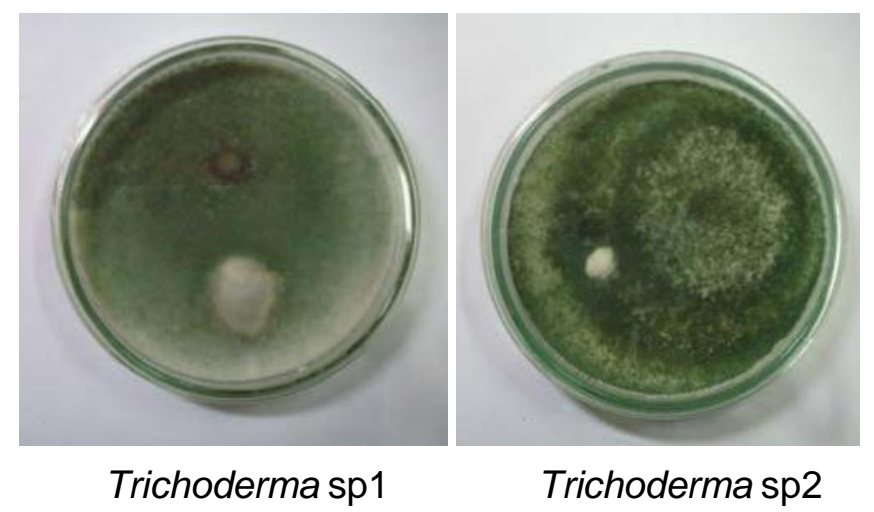

Gambar 2. Hasil pengujian dual test antara Trichoderma dan Ganoderma yang ditumbuhkan pada media PDA umur tujuh hari setelah inokulasi

Pada penelitian ini diperoleh dua isolat Trichoderma yaitu Trichoderma sp1 dan Trichoderma sp2. Berdasarkan beberapa studi terdahulu bahwa Trichoderma mempunyai kemampuan antagonistik yang lebih baik dibandingkan dengan fungi lain, maka pengujian antagonistik dalam penelitian ini hanya dilakukan terhadap Trichoderma saja. Pengujian antagonistik Trichoderma sp1 dan Trichoderma sp2 dilakukan terhadap Ganoderma sp pada media PDA. Hasil pengamatan setelah tujuh hari menunjukkan adanya kemampuan penghambatan pertumbuhan Ganoderma sp baik oleh Trichoderma sp1 maupun Trichoderma sp2 yang ditunjukkan oleh besarnya persentase hambatan yaitu masing-masing $74,42 \%$ oleh Trichoderma sp2 dan $64,94 \%$ oleh Trichoderma sp1 (Gambar 2).

$$
\text { Kemampuan Trichoderma }
$$

dalam menghambat pertumbuhan Ganoderma disebabkan karena Trichoderma bersifat mikoparasit bagi fungi lain (Widyastuti 2006). Mekanisme pengendaliannya terjadi dengan cara membelit atau tumbuh di sepanjang hifa inang (fungi patogen) dan membentuk struktur semacam kait yang membantu penetrasi ke dalam dinding sel inang (Chet et al. 2004).
Penetrasi dinding sel inang oleh Trichoderma dilakukan dengan bantuan enzim pendegradasi dinding sel fungi yang dimilikinya seperti kitinase, glukanase, dan protease, selanjutnya fungi ini menggunakan isi hifa inang sebagai sumber makanan (Kredics et al. 2003; Harjono \& Widyastuti 2001).

Uji pertumbuhan Trichoderma pada kompos

Uji pertumbuhan Trichoderma dilakukan pada dua media tumbuh yaitu kompos kulit buah dan biji kopi. Hasil pengujian menunjukkan bahwa kedua jenis Trichoderma tumbuh lebih baik pada media kompos kulit buah kopi dibandingkan dengan pada media kulit biji kopi, populasinya mencapai $97 \times 10^{5} \quad \mathrm{CFU} / \mathrm{g}$ untuk Trichoderma sp2 dan $74 \times 10^{5} \mathrm{CFU} / \mathrm{g}$ untuk Trichoderma sp1. Hal ini disebabkan karena pada kompos kulit buah kopi teksturnya lembut dan kemungkinan di dalamnya banyak mengandung bahan organik yang dapat mendukung pertumbuhan Trichoderma. Sedangkan pada kulit biji kopi kurang mendukung pertumbuhan Trichoderma karena teksturnya yang keras disebabkan 
oleh tingginya kandungan silika dan senyawa komplek lainnya.

\section{KESIMPULAN}

Jenis fungi yang diperoleh dari tanah perkebunan kopi di Kabupaten Bener Meriah merupakan fungi yang biasa ditemukan dalam tanah, namun kehadiran fungi dari kelompok Aspergillus, Penicillium dan Trichoderma lebih dominan dibandingkan fungi lain. Hasil uji antagonistik menunjukkan bahwa Trichoderma sp2 mempunyai kemampuan yang lebih baik utuk menghambat patogen busuk akar kopi. Media tumbuh yang baik untuk menumbuhkan Trichoderma adalah kompos dari kulit buah kopi.

\section{UCAPAN TERIMA KASIH}

Penelitian ini merupakan bagian dari penelitian Hibah Bersaing tahun anggaran 2011. Penulis mengucapkan terima kasih kepada Direktorat Penelitian dan Pengabdian kepada Masyarakat, Direktorat Jenderal Pendidikan Tinggi Kementerian Pendidikan Nasional yang telah membiayai pelaksanaan penelitian ini.

\section{DAFTAR PUSTAKA}

Adejumo TO (2005) Crop protection strategies for major diseases of cocoa, coffee and cashew in Nigeria. Afric $\mathrm{J}$ Biotech 4 (2):143-150

Breitenbach J, Kranzlin F (1986) Fungi of Switzerland: a contribution to the knowledge of the fungal flora of Switzerland. Lucerne, Switzerland: Verlag Mikologia

Chet I, Viterbo A, Shoresh M, Harel M (2004) Enhancement of plant disease resistance by the biocontrol agent $T$. asperellum. Department of Biological

Chemistrywww.weizmann.ac.il /Biological_Chemistry/scientist
/Chet/Chet.html [21 Desember 2006]

Fisher F, Cook NB (1998) Fundamental of diagnostic mycology. Philadelphia: WB. Sounders Company

Gams W (2007) Biodiversity of soilinhabiting fungi. Biodiver Conserv 16:69-72

Ganjar I, Samson RA, TweelVermeulen $\mathrm{K}$ van den, Oetari A, Santoso I (1999) Pengenalan kapang tropik umum. Jakarta: Yayasan Obor Indonesia.

Ghisalberti EL, Sivasithamparan K (1991) Antifungal antibiotic produced by Trichoderma spp. Soil Biol Biochem 23:10111029

Harjono, Widyastuti SM (2001) Antifungal activity of purified endochitinase produced by biocontrol agent Trichoderma reesei against Ganoderma philippii. Pakistan J Biol Sci 4 (10):1232-1234

Khattabi, N, Ezzahiri B, Lauali L and Oihabi A (2004) Antagonistic activity of Trichoderma isolates against Sclerotium rolfsii: Screening of isolates from Morocco soils for biological control. Phytopathol Mediter 43:332-340

Kredics L, Antal Z, Manczinger L, Szekeres A, Kevei F, Nagy E (2003) Influence of environmental parameters on Trichoderma strains with biocontrol potential. Food Tech Biotech 41 (1): 37-42

Kubicek CP, Harman GE (1998) Trichoderma and Gliocladium, Vol. 1 Basic Biology, taxonomy and genetics. UK, T.J. International Ltd

Mollach D (1997) Moulds: isolation, cultivation, identification. 
Toronto: Department of Botany University of Toronto

Pitt $\mathrm{Jl}$ and Hocking AD (1997) Fungi and food spoilage. $2^{\text {nd }}$ Edition. London: Blackie Academic \& Professional

Samingan, Sutariningsih E, Subagja J (1999) Biodegradasi serasah Acacia Mangium Willd. oleh jamur lignoselulolitik. Teknosains 12(2): 119-133

Samingan, Sudirman, LI, Setiadi D, Hartana A, Tjahjono B (2008) Komunitas mikrofungi pada lapisan serasah Acacia mangium. Jurnal Agrista Faperta Unsyiah 12 (2):131140

Sariah M, Zakaria H (2000) The use of soil amendments for the control of basal stem rot of oilpalm seedling. Dalam: Flood $J$, Bridge PD, Holderness M (eds) Ganoderma diseases of perennial crops. Wallingford, UK: CABI Publishing. pp 8999
Titus A, Pereira GN (2008) Role of fungi in coffee plantation ecology www. Ineed coffee. com/04/ Role of Fungi in Coffee Plantation Ecology [diakses 24 Maret 2008]

Watanabe T (2002) Pictorial atlas of soil and seed fungi, morphologies of cultured fungi and key to species. $2^{\text {nd }}$ Edition. Washington DC: CRC Press

Widyastuti SM (2006) Antagonistic fungi Trichoderma as biological control agents of Ganoderma sp. root rot plant pathogenic fungi. Dalam: Potter K, Rimbawanto A, Beadle C (eds) Workshop Heart Rot and Root Rot in Acacia Plantations. Proceedings of a workshop held in Yogyakarta, Indonesia, 7-9 February 2006. Canberra: Australian Centre for International Agricultural Research 